\title{
Near Threatened Fishes of the World: Malapterurus teugelsi Norris, 2002 (Siluriformes: Malapteruridae)
}

Felix Koffi KONAN (Corresponding author)

Department of Environment, University Jean Lorougnon Guédé, POB 150 Daloa, Ivory Coast

E-mail: konanfelix@yahoo.fr

Charles Koffi BOUSSOU

Department of Environment, University Jean Lorougnon Guédé, POB 150 Daloa, Ivory Coast

E-mail: bkofficharles@live.fr

Yves Kotchi BONY

Department of Environment, University Jean Lorougnon Guédé, POB 150 Daloa, Ivory Coast

E-mail: bonyves@yahoo.fr

Mexmin Koffi KONAN

Department of Sciences and Environment Managment, University Nangui Abrogoua,

02 POB 801 Abidjan 02, Ivory Coast

E-mail: konanmexmin@hotmail.fr

\section{Edia Oi EDIA}

Department of Sciences and Environment Managment, University Nangui Abrogoua,

02 POB 801 Abidjan 02, Ivory Coast

E-mail: square_edia@gmail.com

Boubacar DIALLO

Centre National des Sciences Halieutiques de Boussoura, POB 3738 Conakry, Guinea E-mail: boubadiallo2011@gmail.com

Received: December 30, 2017 Accepted: February 22, 2018 Published: March 3, 2018

doi:10.5296/ast.v6i2.12755 URL: https://doi.org/10.5296/ast.v6i2.12755 


\section{1) Macrothink}

\section{Abstract}

Malapterurus teugelsi Norris, 2002, an endemic electric catfishes of the Kogon River Basin in Guinea, is assessed as Near Threatened due to its restricted distribution area, fishing pressure, mining activities, loss of habitats and aquatic pollution. This fish has a high cultural representation in the folklore of the local population. Moreover, in addition to its very limited distribution, very little information exists on its reproductive biology and its food ecology. Therefore, singular care must be paid to it for its conservation.

Keywords: Malapterurus teugelsi, Malapteruridae, Near Threatened, West Africa

\section{Synonyms}

Malapterurus electricus (Gmelin, 1789) (Teugels, 1992).

\section{Common names}

Freshwater electric catfish (English). "Mirimiriwin" (in Peul, an ethnic group in Guinea).

\section{Taxonomic notes}

Initially regarded with two species (Teugels et al., 1988; Teugels, 1992), genus Malapterurus was reviewed based on morphometric characteristics data by Norris (2002) and Norris (2003) with 16 species in West Africa.

Malapterurus teugelsi were identified in the Kogon River system (Norris, 2002; Norris, 2003; Eschmeyer et al., 2017; Froese \& Pauly, 2017). This species is devoid of dorsal fin and has an adipose fin. The anal fin is composed of 8 to 10 soft rays. The number of vertebrae varies from 38 to 40 .

\section{Geographic Range Information}

Malapterurus teugelsi is endemic to the Kogon River in Guinea (latitude: 1254726.4 / longitude: 554557.1), in west Africa (Norris, 2002; Norris, 2003; Edia et al., 2014). With a length of $379 \mathrm{~km}$, the Kogon River covers a catchment area of $7288 \mathrm{~km}^{2}$ (Richard et al., 2006). The total range of $M$. teugelsi is considered to be less than $1500 \mathrm{~km}^{2}$ (Holland et al., 2012; IFC, 2012; IUCN, 2014).

In this study, Malapterurus teugelsi (Figure 1) was observed in the Ndousihoun stream (latitude: 1227672 / longitude: 632220), a tributary of the Kogon River. It should be noted that this species of electric fish is frequently caught in this river by the riparian populations.

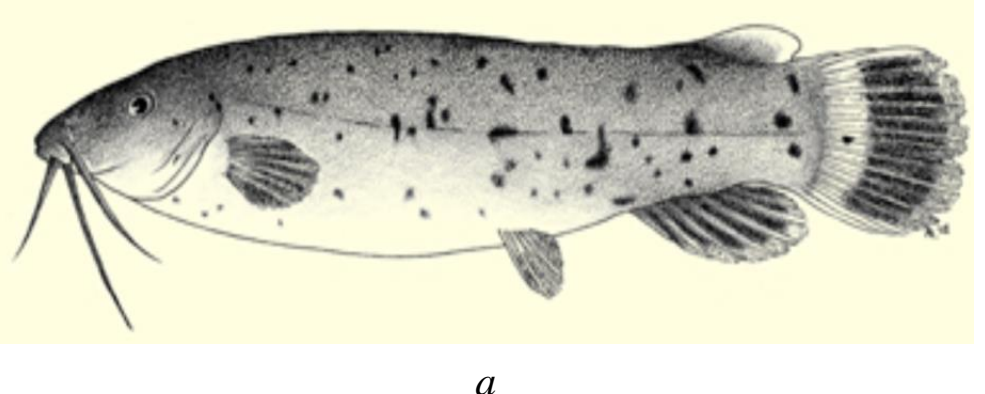




\section{Macrothink

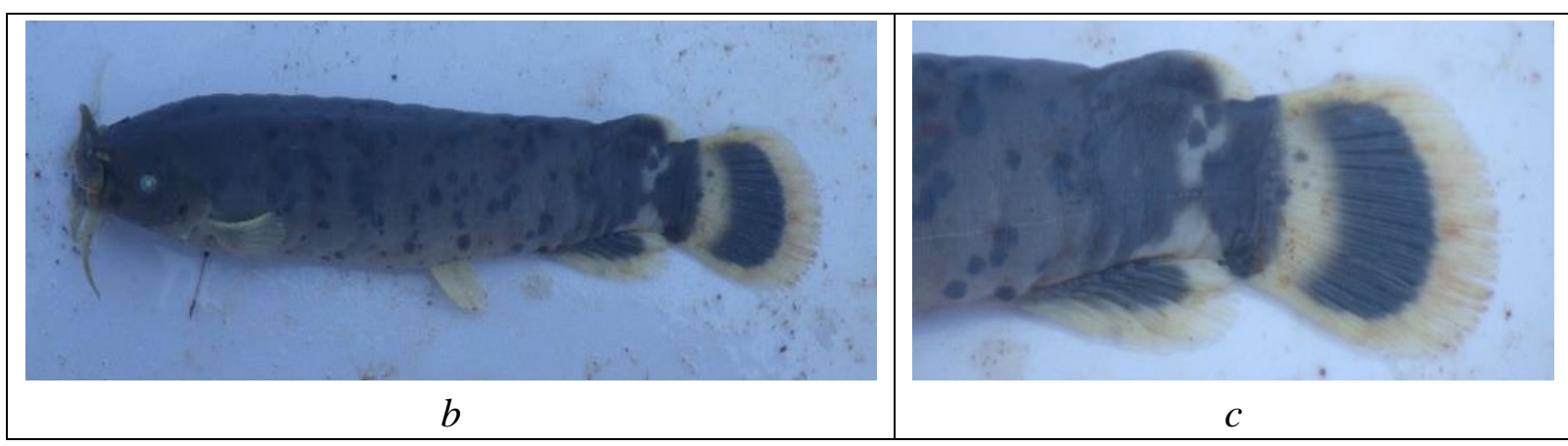

Figure 1. a) Image of Malapterurus teugelsi according to Norris (2001); b) M. teugelsi photography; $c$ ) caudal saddle and bar patterns of $M$. teugelsi from the Ndousihoun River (tributary of Kogon River in Guinea). Photo Courtesy: Felix Koffi KONAN

\section{Fishery and Populations}

Malapterurus teugelsi is sometimes present in artisanal fisheries on the Kogon River basin in Guinea (Norris, 2002; Norris, 2003; Edia et al., 2014). M. teugelsi is regularly caught by fish traps, fishing rods and longlines. The two specimens observed during this study were captured at night using fishing rods.

\section{Habitat and Ecology}

M. teugelsi is a demersal species that inhabits tropical freshwater. In the Ndousihoun stream where this species was observed during this study, the temperature varies between 24.0 $27.4{ }^{\circ} \mathrm{C}$, conductivity between $8.7-77.0 \mu \mathrm{S} . \mathrm{cm}^{-1}$. M. teugelsi was encountered in an area characterized by rocks or roots, calm and slow water with canopy cover of around $70 \%$

\section{Biology}

There is little information on the biology and ecology of this species. Size at first sexual maturity of $M$. teugelsi is $136 \mathrm{~mm}$ in total length (TL) (Froese \& Pauly, 2017). The parameters of the allometric length-weight relationship estimated by Froese et al. (2013) are $a=0.00389(0.00180-0.00842)$ and $b=3.12(2.94-3.30)$. Other population characters and life history information of $M$. teugelsi are following: Trophic level $=3.37$; Length to infinity $=223 \mathrm{~mm}$ (Froese \& Pauly, 2017). According to Cheung et al. (2005), the intrinsic vulnerability to fishing of $M$. teugelsi is estimated at $16 \%$ (low vulnerability). Active at night and highly territorial like most of electric catfish (Polle \& Gosse, 1969; Belbenoit et al., 1979). M. teugelsi is known to feed mainly on fish hunting by stunning its prey with its paralyzing electrical organ (Belbenoit et al., 1979; Froese \& Pauly, 2017). Regarding reproductive biology, nothing much information is available in the literature even for species close to the same geographical area (Polle \& Gosse, 1969; Froese \& Pauly, 2017).

\section{Threats}

Kogon River basin suffers from strong anthropogenic pressure mainly related to bauxite mining activities (Edia et al., 2014). This mining activity has led to water pollution, destabilization of riverbanks, modification of the substrate, high noise level and high concentration of suspended solids. 


\section{Use and trade}

Caught by artisanal fishers on the Kogon Rivers, $M$. teugelsi is much appreciated by the local population. As such, an important source of animal protein and micronutrients in the diet of riparian rural populations.

Moreover, the species belonging to the genus Malapterurus have a high cultural representation in the folklore of the local population as well as in many other West African cultures. For example, his skin is used in traditional medicine for the preparation of certain medication. Used as a nesting aid in some rural communities, the skin of this fish helps protect eggs of chickens against rapacious birds.

\section{Conservation actions}

Anthropic activities on the Kogon River basin must be regulated, and must respect the Performance Standard 6 (IFC, 2012) concerning the conservation of biodiversity and sustainable management of natural living resources.

\section{Acknowledgements}

The author would like to express his gratitude to Sylvatroph-Consulting for financial supports of sampling in the Kogon River basin (Guinea).

\section{References}

Belbenoit, P., Moller, P., Serrier, J., \& Push, S. (1979). Ethological observations on the electric organ discharge behaviour of the electric catfish, Malapterurus electricus (Pisces). Behavioral Ecology and Sociobiology, 4, 321-330.

Cheung, W. W. L., Pitcher, T. J., \& Pauly, D. (2005). A fuzzy logic expert system to estimate intrinsic extinction vulnerabilities of marine fishes to fishing. Biological Conservation, 124, 97-111.

Edia, O. E., Konan, K. M., \& Konan, K. F. (2014). Inventaires des poissons et des macroinvertébrés aquatiques / Etude d'impact environnemental et social du projet d'extension des activités de la Compagnie de Bauxite de Guinée (CBG) (Guinée). Rapport d'étude - Compagnie de Bauxite de Guinée (CBG), Cabinet Sylvatrop Consulting.

Eschmeyer, W. N., Fricke, R., \& van der Laan, R. (Eds). (2017). Catalog of fishes: genera, species, references. (Electronic version accessed on 12 January 2017) (http://researcharchive.calacademy.org/research/ichthyology/catalog/fishcatmain.asp).

Froese, R., \& Pauly, D. (Eds). (2017). FishBase. World Wide Web electronic publication. (Electronic version accessed on 15 December 2017) www.fishbase.org, version (10/2017).

Froese, R., Thorson, J., \& Reyes, Jr. R. B. (2013). A Bayesian approach for estimating length-weight relationships in fishes. Journal of Applied Ichthyology, 29, 1-7.

Holland, R. A., Darwall, W. R. T., \& Smith, K. G. (2012). Conservation priorities for freshwater biodiversity: the Key Biodiversity Area approach refined and tested for continental 
Africa. Biological Conservation, 148, 167-179. https://doi.org/10.1016/j.biocon.2012.01.016

IFC. (2012). Guidance Note 6 Biodiversity Conservation and Sustainable Management of Living Natural Resources. Performance Standards and Guidance Notes - 2012 Edition. Internationale Finance Corporation.

IUCN. (2014). IUCN Red List of Threatened Species. Version 2014.1. IUCN 2014. IUCN Red List of Threatened Species. Downloaded in June 2014.

Norris, S. M. (2002). A revision of the African electric catfishes, family Malapteruridae (Teleostei, Siluriformes), with erection of a new genus and descriptions of fourteen new species, and an annotated bibliography. Ann. Mus. R. Afr. Centr., Sci. Zool., 289, 1-155.

Norris, S. M. (2003). Malapteruridae. p. 174-194. In Lévêque, C., Paugy, D., Teugels, G.G. (Eds), Faune des poissons d'eaux douce et saumâtres de l'Afrique de l'Ouest, Tome 2. Coll. Faune et Flore tropicales 40. Musée Royal de l'Afrique Centrale, Tervuren, Belgique, Museum National d'Histoire Naturelle, Paris, France and Institut de Recherche pour le Développement, Paris, France.

Poll, M., \& Gosse, P. (1969). Revision des Malapteruridae (Pisces, Siluriformes) et description d'une deuxième espèce de silure électrique: Malapterurus microstoma. sp. n. Bull. Inst. r. Sci. nat. Belg., 45, 1-12.

Richard, T., Camara, I. N., Diallo, S. T., Keita, A., \& Bah S. (2006). Rapport national sur l'environnement marin et côtier. GUINEE/PNUE.

Teugels, G. G., Lévêque, C., Paugy, D., \& Traoré, K. (1988). Etat des connaissances sur la faune ichtyologique des bassins côtiers de la Côte d'Ivoire et de l'ouest du Ghana. Revue d'Hydrobiologie tropicale, 21(3), 221-237.

Teugels, G. G. (1992). Malapteruridae. p. 496-499. In: Levêque, C., Paugy, D., Teugels, G.G. (Eds), Faune des poissons d'eaux douces et saumâtres d'Afrique de l'Ouest. Tome 2. Coll. Faune Tropicale $\mathrm{n}^{\circ}$ 28. Musée Royal de l'Afrique Centrale, Tervuren, Belgique and ORSTOM, Paris.

\section{Copyrights}

Copyright for this article is retained by the author(s), with first publication rights granted to the journal.

This is an open-access article distributed under the terms and conditions of the Creative Commons Attribution license (http://creativecommons.org/licenses/by/4.0/) 